Journal of Applied Biosciences 152: 15605 - 15620

ISSN 1997-5902

\title{
Macrofungi diversity in a National Botanical Garden in Southern Côte d'Ivoire
}

\author{
Alix Amenan Djoué1, 2, N'Golo Abdoulaye Koné1, Koua Serge Béranger N'Goran², Louyounan Linda \\ Patricia Vanié-Léabo ${ }^{3}$, Bakary Soro ${ }^{1}$, Denézon Odette Dogbo1 \\ 1 UFR des Sciences de la Nature, Université Nangui Abrogoua, (Abidjan- Côte d'Ivoire) \\ ${ }^{2}$ Centre National de Floristique, Université Félix Houphouët-Boigny (Abidjan- Côte d'Ivoire \\ 3UFR Biosciences, Université Félix Houphouët-Boigny, (Abidjan- Côte d'Ivoire) \\ Corresponding author: alixdjoue@gmail.com
}

Original submitted in on $3^{\text {rd }}$ June 2020. Published online at www.m.elewa.org/journals/ on $31^{\text {st }}$ August 2020 https://doi.org/10.35759/JABs.152.1

\begin{abstract}
Objective: Macrofungi are essential to the structure, functioning and dynamics of ecosystems. In Côte d'Ivoire, studies on macrofungi and the impact of habitats in "Centre National de Floristique (CNF)" on macrofungi diversity are little explored. This study aims to assess macrofungi diversity found in some habitats in the botanical garden.

Methodology and results: A mycological inventory was carried out in three habitat types that differ in the level of anthropisation. The surveys were conducted from 2016 to 2018 during rainy seasons, from MayJuly and October- November and sporophores of 151 morpho-species were collected. They belonged to 5 classes, 12 orders, 26 families and 33 genera. The most abundant species belonging to the Agaricaceae $(19.87 \%)$ followed by Marasmiaceae $(10.60 \%)$ and Polyporaceae $(9.27 \%)$ families. The dominant ecological groups were saprotrophic fungi $(82.00 \%)$. Specific richness was more important in the least visited habitat with 70 species inventoried, followed by the non-visited and the most visited habitat with 54 and 50 species respectively.

Conclusion and application of results: This first investigation on macrofungi showed that CNF is rich in saprotrophic fungi belonging at the Agaricaceae, Marasmiaceae and Polyporaceae family. These saprotrophic fungi have the ecological importance in the forest ecosystem management and conservation. Ours finding constitute a database for the future studies on the mycoflora of the botanical garden. These initial data show the importance of botanical garden in the conservation and biodiversity of mycological resources.
\end{abstract}

Keywords: Macrofungi, Diversity, Botanical garden, Centre National de Floristique (CNF), Côte d'Ivoire

\section{INTRODUCTION}

Tropical forests with their huge biological reservoirs are gradually degrading with population increase. In Africa, this degradation is largely due to agricultural activities and urbanization (FAO, 2016). In Côte d'Ivoire, forest cover has been greatly reduced from 16 to 1.385 million hectares (Koné et al., 2014). Except to a few well-preserved plant formations (reserves and parks), several forest islands and relics are observed mainly in urban areas (Monssou et al., 2016). Thus, it seems 
needful to take measures to safeguard the biodiversity of these forests. Aware of this, Côte d'lvoire has considered since independence to preserve forest resources. This was done by implementing a forest management policy through the creation of forest development corporation and office namely Societé des Forêts (SODEFOR) and Office Ivoirien des Parcs et Reserves (OIPR), respectively (Kouadio et al., 2018). Thus, in 1973 the botanical garden "Centre National de Floristique (CNF)" was created within the Felix Houphouët-Boigny University, Abidjan, Côte d'Ivoire for national floristic diversity conservation. In 1998, the evaluation of this floristic diversity reported about 750 species (CNF, 1998). Currently, inventories carried out estimate it at 445 species (Pagny et al., 2018). Except to the floristic characterizations, very little work has been done on the mycological flora of the CNF. Generally, in Côte d'Ivoire, previous studies carried out on macrofungi has been widely devoted to wild edible

\section{MATERIALS AND METHODS}

Study area: The study was carried out at the National Botanical Garden "Centre National de Floristique (CNF)" in Côte d'Ivoire (Figure 1). CNF is located within the University of Felix Houphouët Boigny, Abidjan, in Southern Côte d'Ivoire. According to Kouadio et al. (2018), CNF is located between $3^{\circ} 57$ and $3^{\circ} 59 \mathrm{~N}$ (Latitude); $5^{\circ} 18$ and $5^{\circ} 20 \mathrm{~W}$ (Longitude) and covers an area of 10.5 ha. The CNF benefits from a humid tropical climate of sub-equatorial type characterized by four seasons: a large and a small rainy season, respectively from April to July and September to November, then a large and a small dry season, respectively from December to March and August to September. The average annual temperature is $26^{\circ} \mathrm{C}$ and the average rainfall is $1658.64 \mathrm{~mm}$. The soil is ferralitic and very desaturated under heavy rainfall (Ouattara, 2016). The CNF consists of a fallow and an arboretum. As reported by Doumbia, (2014), CNF contains most of the Côte d'Ivoire and sub-regional flora, with a significant presence of species with special status (endemic species of Côte d'Ivoire, West African endemic species, species (Koné, 2013; Koné et al., 2018; Yan \& Tiébré, 2018), medicinal species (Soro et al., 2019) and ethnomycology (Kouassi, 2012; Soro, 2020). Moreover, studies relating to the interaction between the diversity and abundance of the macrofungi with the characteristics of the ecosystems which they ensure the balance remain very little provided (Kouassi, 2012; Vanié-Léabo et al., 2017). However, these interactions are the baseline of the structure, dynamics and functioning of ecosystems; especially those in reconstruction. The general objective of the study aims to assess the diversity of macrofungi in a National Botanical Garden "Centre National de Floristique (CNF)" in southern Côte d'Ivoire. The specific objectives are: (1) to inventory the macrofungi species in CNF and determine their ecological characteristics and (2) to estimate the diversity and abundance of macrofungi associated with reconstruction level of habitats.

endangered species, medicinal species, wild foods, etc.) following conservation status defined by the International Union for Conservation of Nature (IUCN). Therefore, this botanical garden ensures exsitu conservation and the preservation of floristic biodiversity. CNF was chosen for its diversity of plant species. Indeed, the garden has an arboretum with of 445 plants species (Pagny et al., 2018). The fallow land is composing by 162 plant species-(Koffi, 2009).

Study design: The study site was subdivided into three habitats, two in the arboretum and one in the fallow for the collection of higher fungi based on the activities carried out there. Habitat 1, located near the offices is the most visited (Figure 1). It is characterized by various activities including study trainings, sightseeing and plot maintenance. In this site, the dead vegetal species are regularly collected and grouped. Habitat 2 is the least frequented and marked by sporadic maintenance and the fallen plant species remain on site. The third habitat is not visited and receives no special maintenance. 


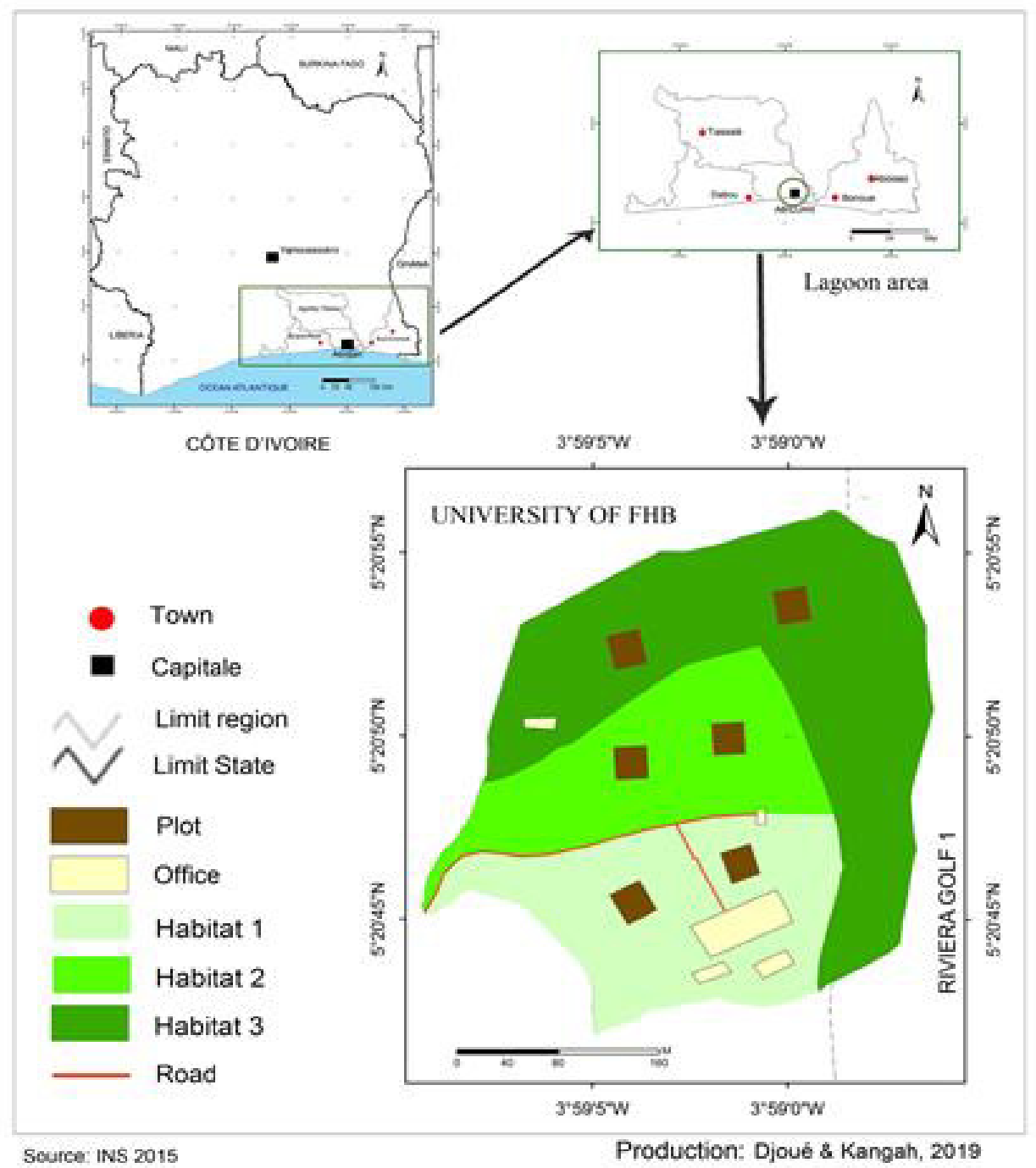

Figure 1: Location of the "Centre National de Floristique" of the University of Felix Houphouët Boigny showing the three studied habitats and various sampled plots.

Data collection: Mycological and floristic inventory were collected in $30 \mathrm{~m} \times 30 \mathrm{~m}$ plot, i.e. $900 \mathrm{~m}^{2}$ in parallel strips of $10 \mathrm{~m}$. Plant species were identified in the field by the botanist. The nomenclature adopted for species identification was that of APG IV (2016). In addition, plant species richness, number of plants per species and per plot was recorded. The sampling of macrofungi specimens was carried out from 2016 to 2018 during the rainy seasons, from May to July and from October to November. It was carried out in two permanent plots of $900 \mathrm{~m}^{2}(30 \mathrm{~m} \times 30 \mathrm{~m})$. The plots were installed randomly in each identified habitat. Opportunistic collections were also made outside the plots to obtain an exhaustive list of fungal species. Macrofungi specimens were collected during the cool hours of the day of two weekly visits per plot. The macrofungi specimens encountered were photographed in situ and preliminary descriptions of macroscopic characteristics were made on the fresh sample. This operation makes it possible to record evanescent or changing data (colour, presence or absence of ring and/or volve) during drying. Subsequently, the macrofungi specimens are removed from their support with a knife and wrapped in paper. They are placed separately in the collection basket away from the sunlight for full morphological description in the laboratory. These macrofungi specimens were dried using an electric dryer (SIPLEC Nsb-200at) at $40{ }^{\circ} \mathrm{C}$ for 24 hours to 48 hours depending on the macrofungi type. After drying, the dried sporophores were stored in Minigrip type 
plastic bags with a label bearing the collection number, date of collection, nature of the substrate and the name of the collector for microscopic studies.

Identification of macrofungi specimens: The collected macrofungi specimens were identified based on habitus, cap shape, colour of the hymenial face and the manner of insertion of the lamellae at the stipe or foot. Spore colour, presence or absence of stipe was also considered. All of these data, and those collected in the field, allowed to group sporophores with common characteristics into morpho-species. The macroscopic study was completed by microscopic examination of the macrofungi specimens. This examination focused on the shapes and sizes of the macrofungi spores. These allowed to identify macrofungi specimens at the genus level and at the specific level for certain species referring to the monographs wrote by De Kesel et al., (2002); Eyi Ndong et al., (2011); Yombiyeni, (2014); Piepenbring, (2015).

Data analysis: Data on the presence and absence of macrofungi specimens were used to determine the species richness (SR: number of species), the list of

\section{RESULTS}

Floristic composition of the studied habitats: Overall, the floristic inventory of the plots was allowed to identify 507 plant specimens distributed 60 families and 171 species belonging to 141 genera. The most represented families with at least 5 species are Fabaceae $(n=32 ; 18.71 \%)$, followed by Malvaceae $(n=$ $19 ; 11.11 \%)$, Apocynaceae ( $n=10 ; 5.85 \%)$, Rubiaceae $(n=8 ; 4.68 \%)$, Sapindaceae and Sapotaceae $(n=7$; $4.09 \%)$ each, Moraceae $(n=6 ; 3.51 \%)$ and species per habitat and the total species richness observed in all habitat types. Thus, the Frequency of Occurrence and Relative Abundance were calculated using Excel 2013 software to indicate the contribution of each species to the community (Kamelan et al., 2013). The Relative Abundance of a macrofungi specimen species corresponds to the ratio of the number of individuals of the same species to the total number of individuals of all species bewildered It provides information on the importance of each species in relation to the total number of species present (Damerdji, 2008).. The assessment of the macrofungi diversity and the regularity of species frequency in habitat types was carried out by calculating the Shannon-Wienner diversity index (H') (Shannon, 1948), the Piélou equitability index (E) (Pielou, 1966) and the Sorensen similarity coefficient (Sorensen, 1948), respectively, using Past 2.17 software. The EstimateS.750 software was used to assess the sampling efficiency in terms of expected and observed macrofungi diversity.

Euphorbiaceae ( $n=5 ; 2.92 \% \%$ ). The remain families have less than 5 species. In this category, 35 monospecific families were recorded and represented $58.33 \%$ of the families inventoried (Figure 2). Regarding to the habitats, the highest species richness was recorded in habitat 3 with 73 species $(42.69 \%)$ of the total species richness versus 62 species $(36.25 \%)$ in habitat 1 and 57 species (33.33\%) in habitat 2. 


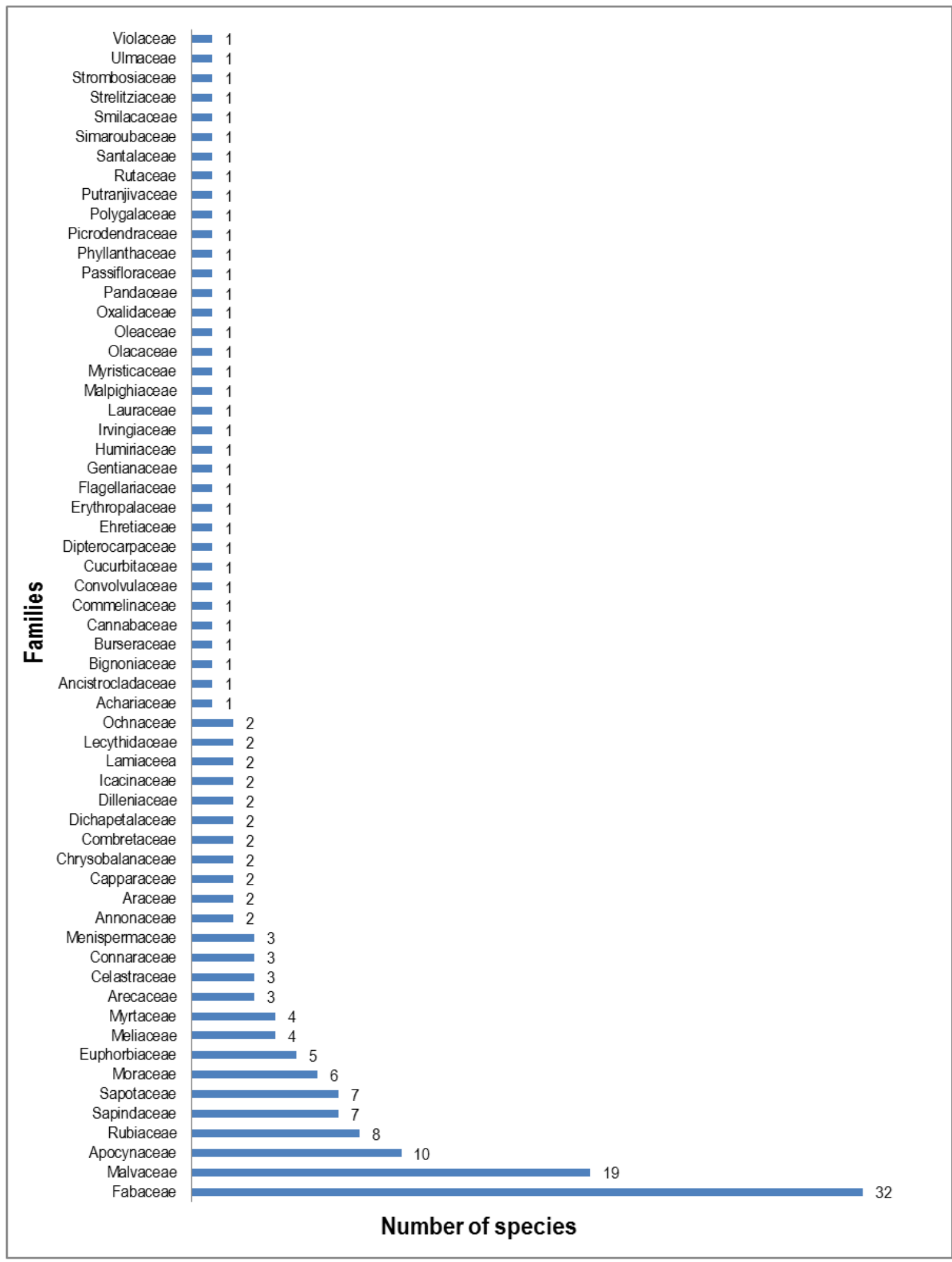

Figure 2: Distribution of species by families. 
Among the most richness families, Fabaceae and Malvaceae were recorded in all habitats. Only, Rubiaceae and Moraceae were represented in habitat 1, and Apocynaceae in both habitat 2 and 3.

Diversity and distribution of CNF macrofungi specimens at the scale of National Botanical Garden "Centre National de Floristique (CNF)": One hundred and fifty-one morpho-species have been identified and grouped into 33 genera belonging to 26 families, 12 orders and five classes. Among these morpho-species, $9.93 \%$ have been identified up to the specific level. The collected sporophores belong to the divisions of Basidiomycota (91\%) and Ascomycota $(9 \%)$. The families having more than ten species are Agaricaceae with $19.87 \%$ of the species, followed by Marasmiaceae (10.60\%) and Polyporaceae (9.27\%), Ganodermataceae and Meruliaceae with 13 species each, either $8.61 \%$ (Figure 3).

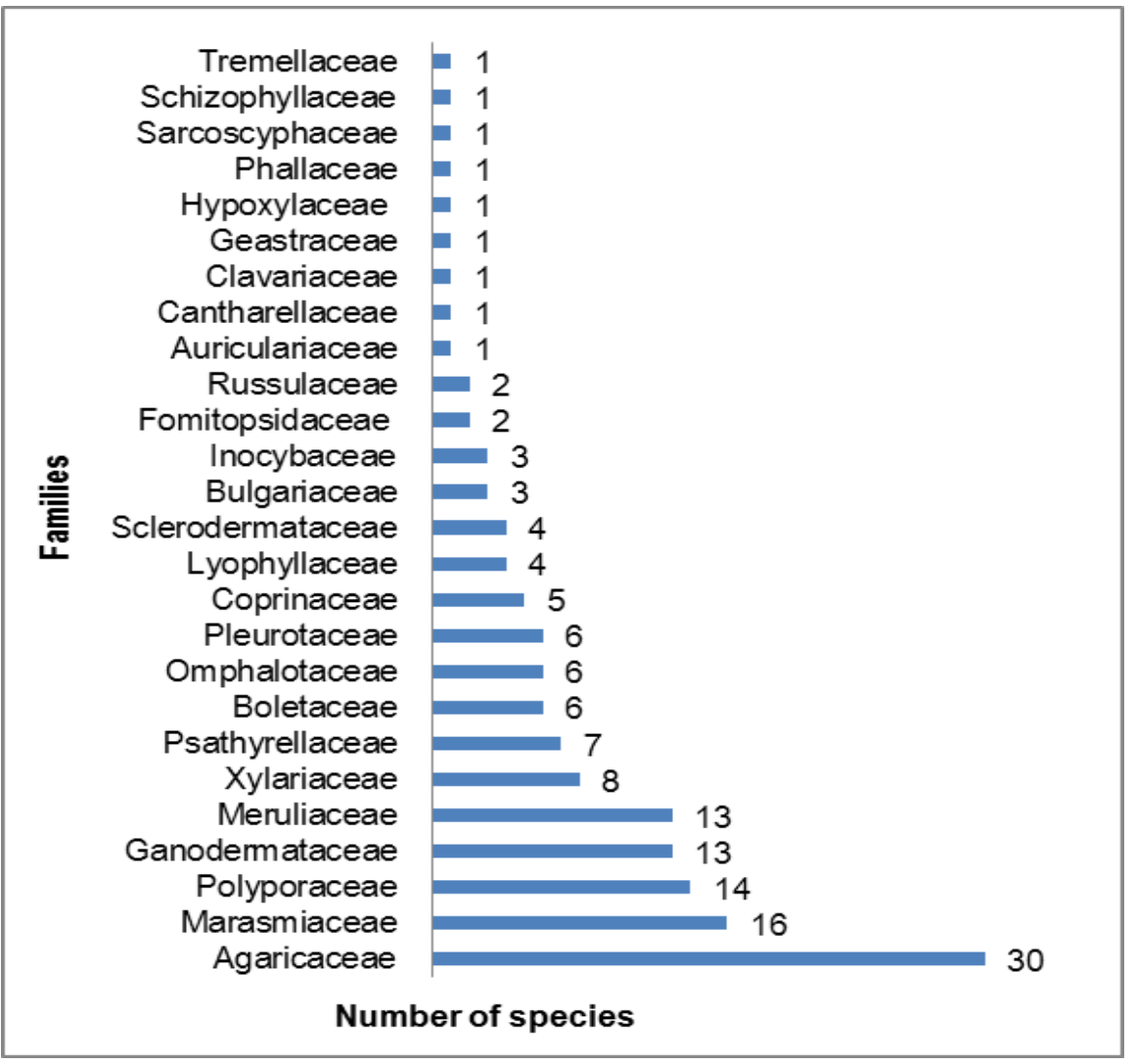

Figure 3: Distribution of macrofungi species in the different families at the scale of National Botanical Garden "Centre National de Floristique.

Within these families, the genus Agaricus (16.55\%) is the most dominant followed by the genera Marasmius (10.59\%), Podoscypha (8.6\%), Ganoderma (5.96\%), Trametes (5.96\%), and Xylaria (5.20\%). Figure 4 illustrates some of the macrofungi harvested at the CNF. 

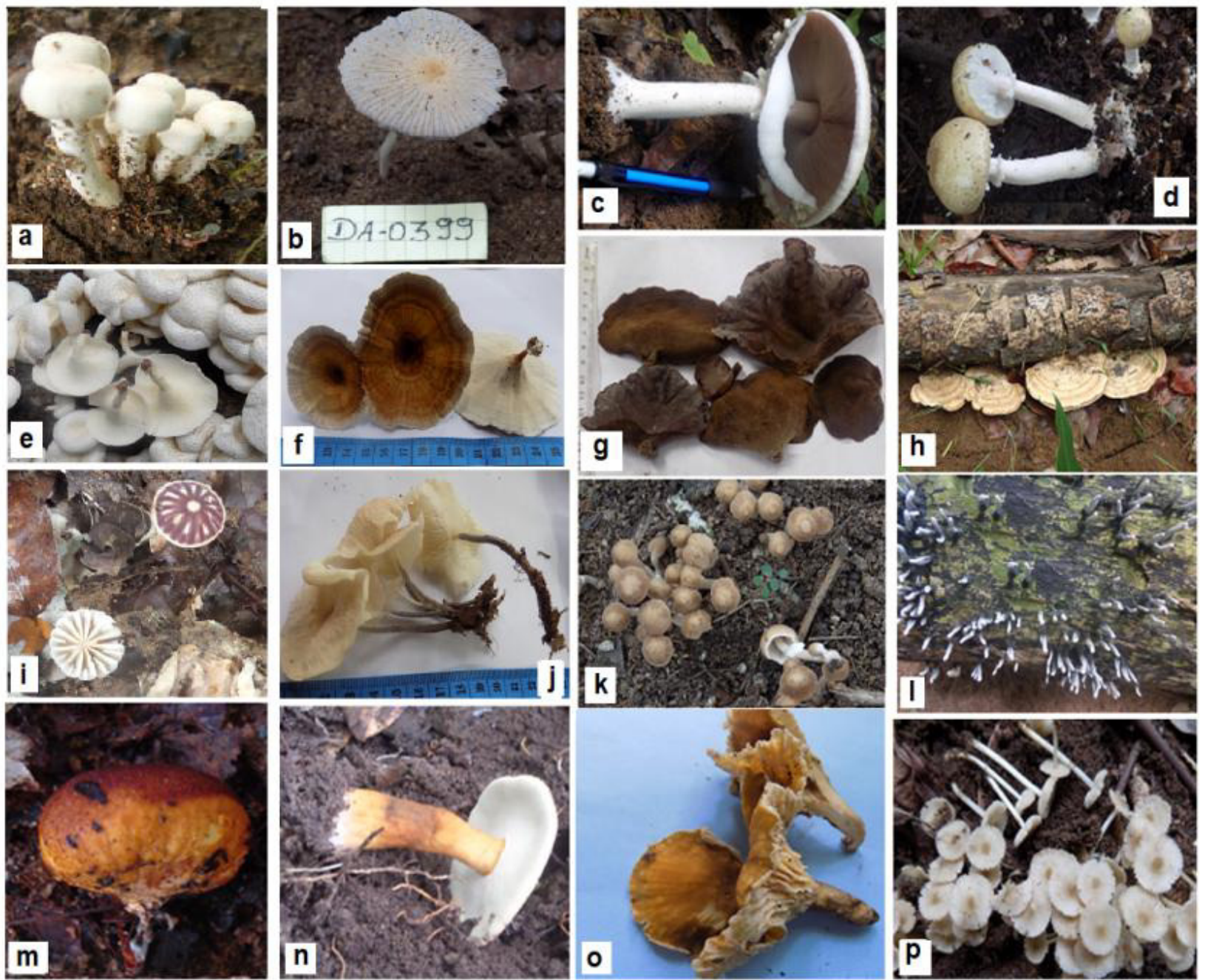

Figure 4: Macrofungi specimens collected at the National Botanical Garden "Centre National de Floristique", Abidjan, Côte d'Ivoire.

(a) Hymeagaricus sp, (b) Leucoagaricus sp3, (c) Agaricus sp12, (d) Agaricus sp13, (e) Lentinus squarrosulus, (f) Pododoscypha sp8, (g) Auricularia Polytricha, (h) Trametes sp8, (i) Marasmius bekoacongoli, (j) Marasmius sp, (k) Psathyrella tuberculata, (I) Xylaria sp1, (m) Scleroderma sp4, (n) Boletus sp1, (o) Cantharellus Luteopunctayus, (p) Termitomycètes microcarpus

Diversity and distribution of macrofungi speciemens at the scale of studied habitats in National Botanical Garden "Centre National de Floristique (CNF)"

Frequency of occurrence of macrofungi and representativeness of sampling: The study showed that the occurrence frequencies ranged from $16.67 \%$ to $50 \%$. Within the habitats 1,2 and $3,(n=45 ; 90 \%)$, $(n=62 ; 88.57 \%)$ and $(n=50 ; 92.60 \%)$ species were enumerated as rare species, respectively. The occurrence frequency was below to $20 \%$. The rangespecies curve showed that the estimated diversity of fungal species in the different habitats is higher than the observed species diversity (Figure 5). 


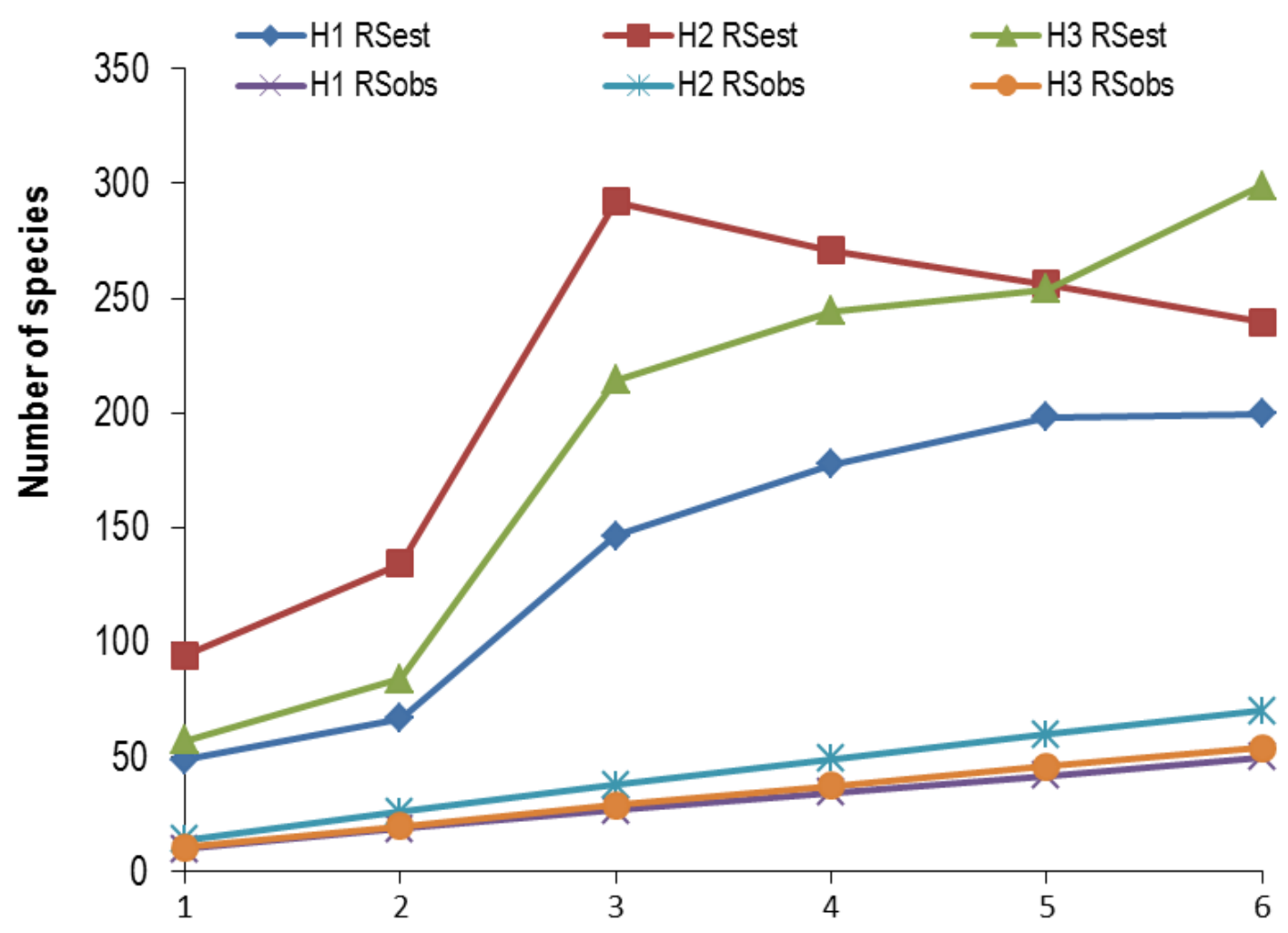

\section{Number of areas}

Figure 5: Curves of fungal species as a function of the areas visited.

$\mathrm{H} 1, \mathrm{H} 2, \mathrm{H} 3$ : Habitats 1, 2 and 3 RSest: Estimated species richness, RSobs: Observed species richness. Nb: the curves $\mathrm{H} 1$ RSobs and $\mathrm{H} 3$ RSobs are merged.

Diversity and distribution of macrofungi: Table1 presents Shannon's diversity and Piélou's equitability indices. Shannon's indices vary between 3.81 and 4.08 bits and remain high $\left(H^{\prime}>3.5\right)$ regardless of habitat type. Piélou equitability tends towards 1 in all habitats. The similarity coefficients between the different habitat types are less than 50\% (Habitat1/Habitat2 (20.00\%), Habitat1/Habitat3 (13.46\%) and Habitat2/Habitat3 $(12.90 \%)$. Figure 6 illustrates the distribution of species richness, number of specific species and species common to the habitats recorded in Table 2. The species richness of fungi varies from one habitat to another. Fifty, 70 and 54 morpho-species were recorded in habitat 1,2 and 3 respectively, although some species are common to the different habitats taken in pairs and others are common between the three habitats. However, some species are common to the different habitats taken in pairs and others are common between the three habitats. We note the presence of 4 morpho-species common to the 3 habitats (Auricularia polytricha, Favolus tenuiculus, Phallus sp, Schizophyllum commune Fr), 3 morphospecies (Marasmius sp1, Clavaria sp1 and Xylaria sp3) common to habitats 1 and 3,8 morpho-species Coprinus sp1, Ganoderma lucidium, Geastrum sp, Lentinus squarrosulus Mont.., Psathyrella Tuberculata, Russula oleifera Buyck, Russula sp and Termitomyces medius are common to habitats 1 and 2 and 4 morphospecies (Marasmius arborescens, Xylaria sp1, Xylaria sp2 and Cookeina speciosa) common to habitats 2 and 3. In addition, 35 morpho-species, 54 morpho-species and 43 morpho-species are specific to habitats 1, 2 and 3 , respectively. 
Table 1: Shannon-Weaver $\left(\mathrm{H}^{\prime}\right)$ and Equipartition $(\mathrm{E})$ diversity indices.

\begin{tabular}{|c|c|c|c|c|}
\hline \multirow{2}{*}{ Habitats } & \multicolumn{2}{|c|}{ Indices de diversity } & & \\
\hline & $\mathrm{RS}$ & $A$ & $\mathrm{H}^{\prime}$ & $E$ \\
\hline Habitat 1 & 50 & 55 & 3.81 & 0.97 \\
\hline Habitat 2 & 70 & 78 & 4.08 & 0.96 \\
\hline Habitat 3 & 54 & 58 & 3.89 & 0.97 \\
\hline
\end{tabular}

RS: Specific Richness, A: Abundance; H': Shannon index; E: Equitability index

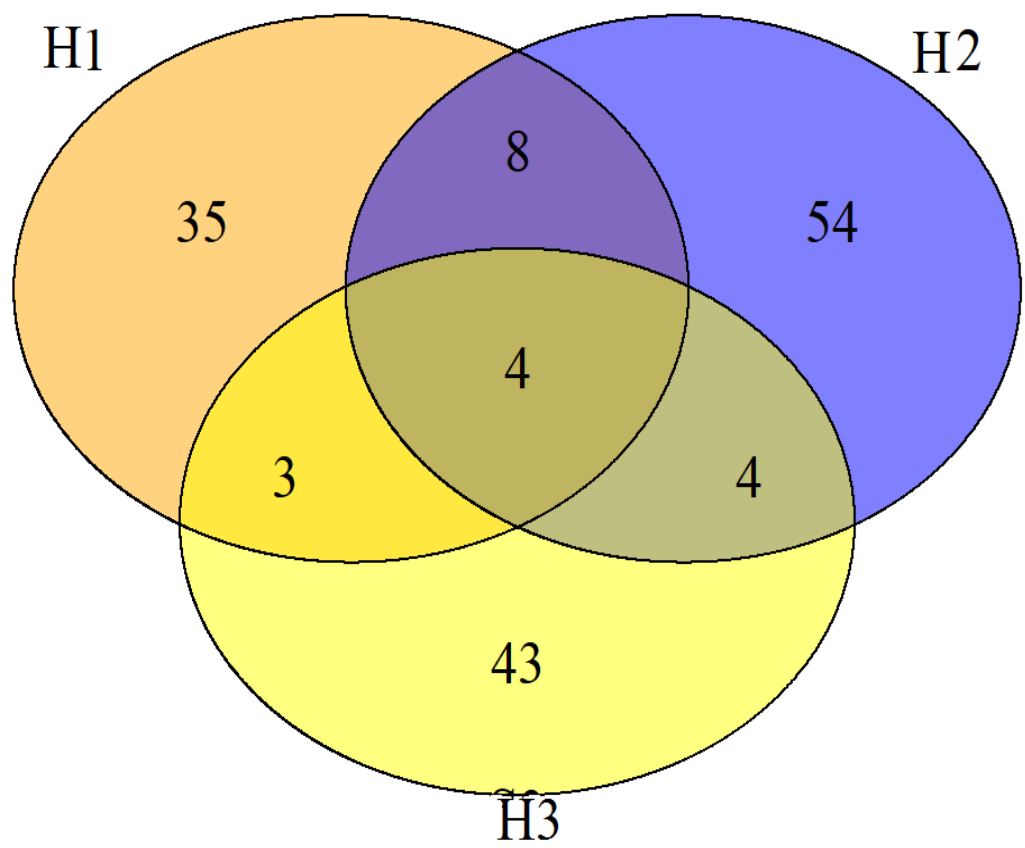

Figure 6: Number of macrofungi species specific or common to three studied habitats.

Table 2: Presence or absence of the macrofungi specimens in three studied habitats.

\begin{tabular}{llccc}
\hline Family & species & Habitat 1 & Habitat 2 & Habitat 3 \\
\hline Agaricaceae & Agaricus erythrotrichus Heinem & 0 & 1 & 0 \\
& Agaricus sp1 & 0 & 1 & 0 \\
Agaricus sp2 & 1 & 0 & 0 \\
Agaricus sp3 & 1 & 0 & 0 \\
Agaricus sp4 & 0 & 0 & 1 \\
Agaricus sp5 & 0 & 1 & 0 \\
Agaricus sp6 & 0 & 0 & 1 \\
Agaricus sp7 & 0 & 1 & 1 \\
Agaricus sp8 & 0 & 0 & 1 \\
Agaricus sp9 & 0 & 0 & 1 \\
Agaricus sp10 & 0 & 0 & 0 \\
Agaricus sp11 & 1 & 0 & 1 \\
Agaricus sp12 & 0 & 0 & 0 \\
Agaricus sp13 & 0 & 0 & 0 \\
Agaricus sp14 & 0 & 1 & 0 \\
Agaricus sp15 & 0 & 1 & 0
\end{tabular}


Auriculariaceae

Boletaceae
Bulgariaceae
Cantharellaceae
Clavariaceae
Coprinaceae

Fomitopsidaceae

Ganodermataceae

Geastraceae

Hypoxylaceae

Inocybaceae

Lyophyllaceae

Marasmiaceae

Agaricus sp18
Agaricus sp19
Agaricus sp20
Agaricus sp21
Agaricus sp22
Agaricus sp23
Agaricus sp24
Chlorophyllum sp
Hymeagaricus sp
Leucocoprinus sp1
Leucocoprinus sp2
Leucocoprinus sp3
Auricularia polytricha
Boletus sp1
Boletus sp2
Boletus sp3
Boletus sp4
Boletus sp5
Boletus sp6
Bulgaria sp1
Bulgaria sp2
Bulgaria sp3
Cantharellus luteopunctatus
Clavaria sp
Coprinus africana
Coprinus sp1
Coprinus sp2
Coprinus sp3
Coprinus sp4
Daedalea sp
Phaeolus sp
Amauroderma sp1
Amauroderma sp2
Amauroderma sp3
Amauroderma sp4
Ganoderma lucidium
Ganoderma sp1
Ganoderma sp2
Ganoderma sp3
Ganoderma sp4
Ganoderma sp5
Ganoderma sp6
Ganoderma sp7
Ganoderma sp8
Geastrum sp
Daldinia concentrica
Crepidotus sp1
Crepidotus sp2
Crepidotus sp3
Termitomyces medius
Termitomyces microcarpus
Termitomyces sp1
Termitomyces sp2
Marasmius arborescens
Marasmius bekolacongoli Beeli

Agaricus sp18

Agaricus sp20

Agaricus sp21

Agaricus sp22

Agaricus sp23

Agricus sp24

Chlorophyllum sp

Leucocoprinus sp1

Leucocoprinus sp2

Leucocoprinus sp3

Boletus sp1

Boletus sp2

Boletus sp3

Boletus sp4

Boletus sp5

Bulgaria sp2

Bulgaria sp3

Cantharellus luteopunctatus

Clavaria sp

Coprinus africana

Coprinus sp4

Amauroderma sp1

Amauroderma sp2

Amauroderma sp3

Ganoderma sp1

Ganoderma sp2

Ganoderma sp3

Ganoderma sp4

Ganoderma sp5

Ganoderma sp6

Ganoderma sp7

Ganoderma sp8

Daldinia concentrica

Crepidotus sp1

Crepidotus sp2

Termitomyces medius

Termitomyces microcarpus

Termitomyces sp2

Marasmius bekolacongoli Beeli

15614

\begin{tabular}{|c|c|c|}
\hline 1 & 0 & 0 \\
\hline 1 & 0 & 0 \\
\hline 1 & 0 & 0 \\
\hline 1 & 0 & 0 \\
\hline 0 & 1 & 0 \\
\hline 0 & 1 & 0 \\
\hline 1 & 0 & 0 \\
\hline 1 & 0 & 0 \\
\hline 0 & 1 & 0 \\
\hline 0 & 1 & 0 \\
\hline 0 & 0 & 1 \\
\hline 0 & 1 & 0 \\
\hline 1 & 1 & 1 \\
\hline 1 & 0 & 0 \\
\hline 1 & 0 & 0 \\
\hline 0 & 1 & 0 \\
\hline 0 & 1 & 0 \\
\hline 1 & 0 & 0 \\
\hline 0 & 0 & 1 \\
\hline 0 & 1 & 0 \\
\hline 0 & 1 & 0 \\
\hline 1 & 0 & 0 \\
\hline 0 & 0 & 1 \\
\hline 1 & 0 & 1 \\
\hline 0 & 0 & 1 \\
\hline 1 & 1 & 0 \\
\hline 0 & 0 & 1 \\
\hline 0 & 1 & 0 \\
\hline 0 & 0 & 1 \\
\hline 1 & 0 & 0 \\
\hline 0 & 1 & 0 \\
\hline 0 & 1 & 0 \\
\hline 1 & 0 & 0 \\
\hline 1 & 0 & 0 \\
\hline 0 & 1 & 0 \\
\hline 1 & 1 & 0 \\
\hline 0 & 0 & 1 \\
\hline 0 & 0 & 1 \\
\hline 0 & 1 & 0 \\
\hline 0 & 1 & 0 \\
\hline 0 & 0 & 1 \\
\hline 0 & 0 & 1 \\
\hline 0 & 1 & 0 \\
\hline 1 & 0 & 0 \\
\hline 1 & 1 & 0 \\
\hline 0 & 1 & 0 \\
\hline 0 & 1 & 0 \\
\hline 0 & 1 & 0 \\
\hline 0 & 1 & 0 \\
\hline 1 & 1 & 0 \\
\hline 1 & 0 & 0 \\
\hline 0 & 1 & 0 \\
\hline 0 & 1 & 0 \\
\hline 0 & 1 & 1 \\
\hline 0 & 0 & 1 \\
\hline
\end{tabular}




\begin{tabular}{|c|c|c|c|c|}
\hline & Marasmius sp1 & 1 & 0 & 1 \\
\hline & Marasmius sp2 & 0 & 0 & 1 \\
\hline & Marasmius sp3 & 0 & 1 & 0 \\
\hline & Marasmius sp4 & 0 & 0 & 1 \\
\hline & Marasmius sp5 & 0 & 0 & 1 \\
\hline & Marasmius sp6 & 0 & 0 & 1 \\
\hline & Marasmius sp7 & 0 & 0 & 1 \\
\hline & Marasmius sp8 & 0 & 0 & 1 \\
\hline & Marasmius sp9 & 0 & 1 & 0 \\
\hline & Marasmius sp1 & 0 & 1 & 0 \\
\hline & Marasmius sp11 & 0 & 1 & 0 \\
\hline & Marasmius sp12 & 0 & 0 & 1 \\
\hline & Marasmius sp13 & 1 & 0 & 0 \\
\hline & Marasmius sp14 & 0 & 1 & 0 \\
\hline Meruliaceae & Podoscypha sp1 & 0 & 0 & 1 \\
\hline & Podoscypha sp2 & 1 & 0 & 0 \\
\hline & Podoscypha sp3 & 0 & 0 & 1 \\
\hline & Podoscypha sp4 & 0 & 0 & 1 \\
\hline & Podoscypha sp5 & 1 & 0 & 0 \\
\hline & Podoscypha sp6 & 0 & 1 & 0 \\
\hline & Podoscypha sp7 & 0 & 0 & 1 \\
\hline & Podoscypha sp8 & 0 & 0 & 1 \\
\hline & Podoscypha sp9 & 0 & 1 & 0 \\
\hline & Podoscypha sp10 & 1 & 0 & 0 \\
\hline & Podoscypha sp11 & 0 & 1 & 0 \\
\hline & Podoscypha sp12 & 0 & 1 & 0 \\
\hline & Podoscypha sp13 & 1 & 0 & 0 \\
\hline Omphalotaceae & Marasmiellus sp1 & 0 & 0 & 1 \\
\hline & Marasmiellus sp2 & 0 & 1 & 0 \\
\hline & Marasmiellus sp3 & 0 & 1 & 0 \\
\hline & Marasmiellus sp4 & 0 & 1 & 0 \\
\hline & Marasmiellus sp5 & 1 & 0 & 0 \\
\hline & Marasmiellus sp6 & 0 & 1 & 0 \\
\hline Phallaceae & Phallus sp & 1 & 1 & 1 \\
\hline Pleurotaceae & Pleurotus sp1 & 0 & 0 & 1 \\
\hline & Pleurotus sp2 & 0 & 1 & 0 \\
\hline & Pleurotus sp3 & 0 & 0 & \\
\hline & Pleurotus sp4 & 0 & 1 & 0 \\
\hline & Pleurotus sp5 & 0 & 1 & 0 \\
\hline & Pleurotus sp6 & 0 & 0 & \\
\hline Polyporaceae & Favolus sp & 0 & 1 & ( \\
\hline & Favolus tenuiculus & 1 & 1 & \\
\hline & Lentinus sp1 & 0 & 0 & \\
\hline & Lentinus sp2 & 1 & 0 & \\
\hline & Lentinus Squarrosulus & 1 & 1 & 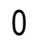 \\
\hline & Trametes sp1 & 1 & 0 & \\
\hline & Trametes sp2 & 0 & 0 & \\
\hline & Trametes sp3 & 0 & 1 & \\
\hline & Trametes sp4 & 0 & 0 & \\
\hline & Trametes sp5 & 0 & 0 & \\
\hline & Trametes sp6 & 0 & 0 & \\
\hline & Trametes sp7 & 0 & 0 & \\
\hline & Trametes sp8 & 0 & 1 & \\
\hline & Trametes sp9 & 1 & 0 & \\
\hline Psathyrellaceae & Psathyrella tuberculata & 1 & 1 & \\
\hline
\end{tabular}




\begin{tabular}{|c|c|c|c|c|}
\hline & Psathyrella sp1 & 1 & 0 & 0 \\
\hline & Psathyrella sp2 & 0 & 1 & 0 \\
\hline & Psathyrella sp3 & 0 & 1 & 0 \\
\hline & Psathyrella sp4 & 0 & 1 & 0 \\
\hline & Psathyrella sp5 & 0 & 1 & 0 \\
\hline & Psathyrella sp6 & 0 & 1 & 0 \\
\hline \multirow[t]{2}{*}{ Russulaceae } & Russula oleifera Buyck & 1 & 1 & 0 \\
\hline & Russula sp & 1 & 1 & 0 \\
\hline Sarcoscyphaceae & Cookeina speciosa & 0 & 1 & 1 \\
\hline Schizophyllaceae & Schizophyllum commune Fr. & 1 & 1 & 1 \\
\hline \multirow[t]{4}{*}{ Sclerodermataceae } & Scleroderma sp1 & 0 & 0 & 1 \\
\hline & Scleroderma sp2 & 1 & 0 & 0 \\
\hline & Scleroderma sp3 & 1 & 0 & 0 \\
\hline & Scleroderma sp4 & 0 & 1 & 0 \\
\hline Tremellaceae & Tremella sp & 0 & 0 & 1 \\
\hline \multirow[t]{8}{*}{ Xylariaceae } & Xylaria sp1 & 0 & 1 & 1 \\
\hline & Xylaria sp2 & 0 & 1 & 1 \\
\hline & Xylaria sp3 & 1 & 0 & 1 \\
\hline & Xylaria sp4 & 0 & 1 & 0 \\
\hline & Xylaria sp5 & 1 & 0 & 0 \\
\hline & Xylaria sp6 & 1 & 0 & 0 \\
\hline & Xylaria sp7 & 0 & 0 & 1 \\
\hline & Xylaria sp8 & 1 & 0 & 0 \\
\hline Total & & 50 & 70 & 54 \\
\hline
\end{tabular}

1: presence of the macrofungi specimen; 0 : absence of the macrofungi specimen

Ecological characteristics of macrofungi specimens: Within the habitats, the collected sporophores are unequally distributed in three ecological groups. Among these groups, habitat 3 has the highest number of saprotrophic species (87\%), followed by symbiotic species $(6 \%)$ and parasitic species (7\%). Regarding to the habitat $2,82 \%$ of saprotrophic species, $11 \%$ symbiotic species and $7 \%$ parasitic species were recorded. In habitat 1 , saprotrophic species (78\%) were the most collected, followed by symbiotic species (18\%) and parasitic species (4\%) (Figure 7). Overall, the different ecological groups encountered are essentially represented by saprotrophs (82.12\%), symbionts (11.26\%) and parasites (6.62\%). Among symbiotic fungi, ectomycorrhizal species were the most represented with $8.61 \%$ of the species collected. Saprotrophic fungi dominate all habitats, with a high richness within the habitat 2 (37.75\%) (Table 3). 

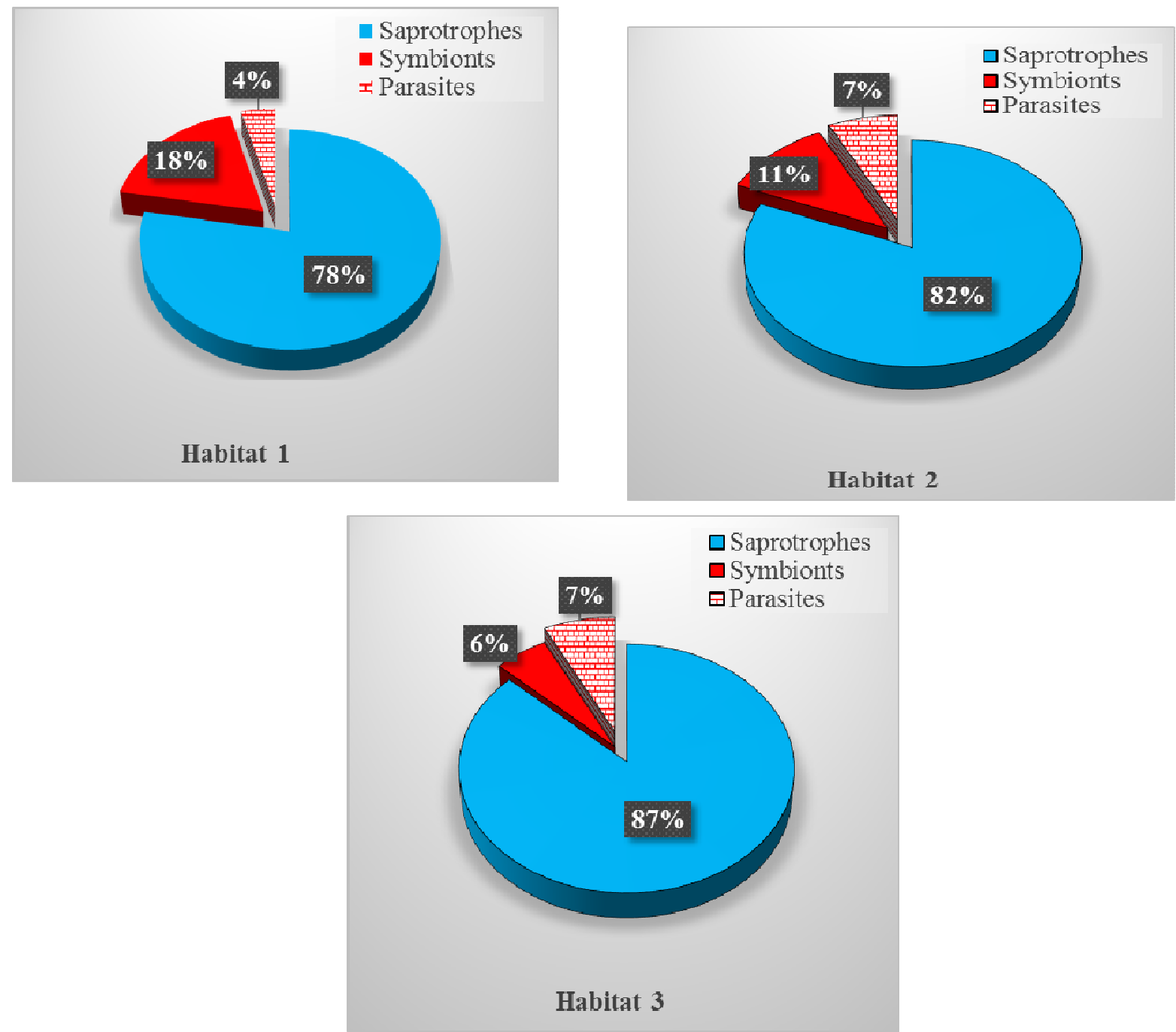

Figure 7: Distribution of morpho-species in ecological groups by habitat.

Table 3: Distribution of abundance of ecological groups of macrofungi specimens according to studied habitats.

\begin{tabular}{l|l|l|l|l}
\hline \multirow{2}{*}{ Ecological groups of fungi } & \multicolumn{3}{|c|}{ Habitats } & \multirow{2}{*}{ Total diversity } \\
\cline { 2 - 4 } & \multicolumn{1}{|c|}{ Habitat 1 } & \multicolumn{1}{|c}{ Habitat 2 } & \multicolumn{1}{c}{ Habitat 3 } & \\
\hline Saprotrophes & $39(25.83 \%)$ & $57(37.75 \%)$ & $47(31.13)$ & $124(82.12 \%)$ \\
Parasites & $02(1.32 \%)$ & $05(3.31 \%)$ & $04(2.65 \%)$ & $10(6.62 \%)$ \\
Termitophilic symbionts & $02(1.32 \%)$ & $03(1.99 \%)$ & $00(0.00)$ & $04(2.65 \%)$ \\
Ectomycorrhizal Symbionts & $07(4.64 \%)$ & $05(3.31 \%)$ & $03(1.99 \%)$ & $13(8.61 \%)$ \\
Total & $50(33.11 \%)$ & $70(46.36)$ & $54(35.75)$ & $151(100 \%)$ \\
\hline
\end{tabular}

\section{DISCUSSION}

This study identifying 151 morpho-species distributed into 33 genera, 26 families and 12 orders. Among these morpho-species, $10 \%$ were identified up to the specific level. The lack of mycologists and identification keys on tropical fungi in general, and those of Côte d'lvoire could explain the low rate of the identified species in particular. Kamou et al. (2017) also reported this observation in study conducted in the FazaoMalfakassa National Park in Togo. These authors inventoried a substantial number of fungal species due to the large size of the collection area and the nature of the plant formations, but only $40 \%$ of these species 
could be identified at the specific level. According to Flores et al. (2011), many countries in Sub-Saharan Africa do not have data on the specific diversity of macrofungi in the different types of plant formations to date. However, the study carried out on macrofungi has always focused on edible and/or ectomychorizial fungi (Koné et al., 2011; Léabo-Vanié et al., 2017; Koné et al., 2018). Macrofungi diversity was high in the three habitats sampled in CNF. Habitat 2 recorded the highest macrofungi species diversity and species richness. This may be because this habitat is less frequented and hosts a large number of dead plant species from windfall and undercutting. Habitats 1 and 3 were recorded lower macrofungi species diversity and richness. This could be explained by the fact that habitat 1 is more exhibited and accessible to staff and visitors and thus, able to be disturbed. As for habitat 3 , the low diversity could be due to the presence of shadowing an insignificant number of dead plant species (twigs, branches). Shannon diversity index calculated for each habitat showed above-average values $\left(H^{\prime}>3.5\right)$, and represented 3.81, 4.08 and 3.89 bits for habitats 1, 2 and 3, respectively. This suggests that the CNF contains a higher diversity of fungi. This diversity could be linked to the various substrates, the nature of the soil and the climatic conditions of the environment and to anthropogenic activities. Moreover, the similarity index showed no similarity within the collection habitats, confirming that the fungal list of habitats is not identical. In fact, some sporophores were collected on soil with varying degrees of humus, others on decaying or non-decaying wood of various plant species and on dead leaves. During this study, a relatively high number of genera and families of fungi were recorded. This could be due to the diversity of plant species, as well as the availability of resources encountered within the habitats. Similar results were observed by Kouassi (2012) in the classified forests of Bouaflé, Bayota and Niégré in Côte d'Ivoire. Overall, 151 specimens of the macrofungi were inventoried. This species richness is relatively low compared to the estimated total richness of the CNF's macrofungi. Indeed, the floristic richness of the CNF is estimated at 607 species (Koffi 2009; Kouamé, 2013). This floristic richness allows estimating the diversity of fungi at nearly 3642 species, with approximately 809 macrofungi. Thus, the diversity of fungal species estimated in the different habitats is much higher than that of the observed species. This difference could be due to the method used to estimate fungal diversity, which was based on fruiting bodies appearing on various substrates and not mycelium (Yorou, 2010). Fungi fruiting bodies are relatively short-lived organisms. They could carry fruit just after the daily harvest and die before the second harvest. The CNF remaining a research site regularly welcomes visitors who collect sporophores for an observation of curiosity sometimes linked to shape and colour. In addition, the maintenance service through their passages tramples daily and crushes the primoduim (sporophores at the beginning of fruiting) by inattention. The lack of collectors for a complete sampling of the area during our various passages could be a limiting factor to the high diversity and richness observed. All these factors also influence the fungal cover with frequencies of appearance varying from $16.67 \%$ to $50.00 \%$. In addition, this study revealed about $90 \%$ of rare species, which could be due to the biological requirements of these organisms, related to biotic and/or abiotic factors. The collected sporophores belong to different ecological groups. The diversity of fungi is dominated by saprotrophic species, which contribute $82 \%$ of the specific richness of the sporophores recorded, compared with $13 \%$ of symbionts and $5 \%$ of parasites. This unequal distribution of sporophores found within the different ecological groups is linked to the location of the CNF and its richness in floristic species. In addition, the high richness in saprotrophic species is due to an accumulation of deadwoods contributing to the successive fructification of different species specific to the plant species. These results corroborate with those of Yorou et al., (2017), who showed that saprotrophic fungi are abundant in forest areas. The simultaneous presence of all trophic groups of fungi would be favoured by the existence of various forest, savannah and even ectomycorrhizal host plant species (Burkea africana, Afzelia africana, etc.) that are present in the study site. Moreover, as trees age, the presence of a significant number of dead trees, twigs or leaves at various stages of decomposition would explain the existence of saprotrophic fungi. The low rate of ectomycorrhizal species recorded could be explained by the introduction of host plant species in the study area. According to Yorou and De Kessel, (2011), ectomychorizial fungi would be more abundant in open forests than in dense forests. This high diversity would be due to storage of dead plant material favouring the successive fructification of different species specific to each stage of decomposition of the plant species. 


\section{CONCLUSION AND APPLICATION OF RESULTS}

The diversity of the macrofungi differs from one habitat to another. Macrofungi diversity differs from one habitat to another. The most encountered families are Agaricaceae, Marasmiaceae and Polyporaceae. Saprotrophic fungi were the most represented in all three habitats. The least frequented habitat contained the greatest number of fungal species and habitat 3 was the least rich. Habitats 1 and 2 located in the arboretum were dominated by Agaricaceae and habitat
3 located in the fallow was characterized by Marasmiaceae. This study will provide data on the diversity of this biological heritage. It will constitute a reference mycological database for the future investigations in this field. For a better knowledge of the biodiversity of botanic garden, further studies on CNF macrofungi would be necessary in order to establish an exhaustive list and a mycological herbarium following the example for plant species.

\section{ACKNOWLEDGMENTS}

The authors thank the Director of the "Centre National de Floristique" and his staff for making its site available for the collection of sporophores. We would also like to thank all people who have helped us to conduct this study.

\section{REFERENCES}

APG IV, 2016. An update of the Angiosperm Phylogeny Group classification for the orders and families of flowering plants. Botanical Journal of the Linnean Society. 181: 1-20.

CNF, 1998. Le CNF, un patrimoine national, voire mondial à sauvegarder. CNF, Université Félix Houphouët-Boigny, Abidjan, Côte d'Ivoire. 15 p.

Damerdji $A, 2008$. Contribution à l'étude écologique de la malacofaune de la zone Sud de la région de Tlemcen (Algérie). Afrique Science 04: 138153.

De Kesel A, Codjia JTC, Yorou SN, 2002. Guide des Champignons Comestibles du Bénin. Centre International d'Écodéveloppement Intégré (CECODI). Coco-Multimédia, Cotonou, République du Bénin et Jardin Botanique National de Belgique. $273 p$.

Doumbia M, 2014. Diversité caractéristique, Biomorphologie des espèces à statut Particulier de l'arboretum du Centre National de Floristique de I'Université Félix Houphouët Boigny. Mémoire de DEA de Biologie Végétale (Option Ecologie Végétale), UFR Biosciences Université Félix Houphouët Boigny, Abidjan, Côte d'Ivoire, $47 \mathrm{p}$.

Eyi-Ndong H, Degreef J, De Kesel A, 2011. Champignons comestibles des forêts denses d'Afrique Centrale. Taxonomie et identification. abc taxa, Bruxelles 10: $255 \mathrm{p}$.

FAO, 2016. Situation des forêts du monde. Forêts et agriculture: défis et possibilités concernant l'utilisation des terres. Rome. 137 p.
Flores Arzu R, Comandini O, Rinaldi A, 2012. A preliminary checklist of macrofungi of Guatemala, with notes on edibility and traditional knowledge. Mycosphere 3: 1-21.

Kamelan TM, YAO SS, Kouamé KA, Konan G, N'ZI KG et Kouamélan EP, 2013. Ichtyofaune de la rivière Dodo (Côte d'Ivoire, Afrique de l'ouest) : mise à jour et influence des variables environnementales sur la distribution des espèces. Journal of Applied Biosciences 71: 5773-5785.

Kamou H, Gbogbo KA, Yorou NS, Nadjombe P, AbaloLoko AG, Verbeken A, Guelly A, 2017. Inventaire préliminaire des macromycètes du Parc National Fazao-Malfakassa du Togo, Afrique de l'Ouest. Tropicultura 35: 275-287.

Koné M, Kouadio YL, Neuba DFR, Malan DF, Coulibaly $L, 2014$. Evolution de la couverture forestière de la Côte d'Ivoire des années 1960 au début du $21 \mathrm{e}$ siècle. International Journal of Innovation and Applied Studies 7: 782-794.

Koné NA, Soro B, Vanié-Léabo LPL, Konaté S, Bakayoko A, Koné D, 2018. Diversity, phenology and distribution of Termitomyces species in Côte d'Ivoire. Mycology 9: 307-315.

Koné NA, Yéo K, Konaté S, Linsenmair KE, 2013. Socio-economical aspects of the exploitation of Termitomyces fruit bodies in central and southern Côte d'Ivoire: Raising awareness for their sustainable use. Journal of Applied Biosciences 70: 5580-5590.

Koné NA, Dosso K, Konaté S, Kouadio YJ, Linsenmair $\mathrm{KE}$, 2011. Environmental and biological determinants of Termitomyces species 
seasonal fructification in central and southern Côte d'Ivoire. Insectes Sociaux 58: 371-382.

Kouadio K, Dibi NH, N'Goran KSB, Ouattara SFP, 2018. Diversité des espèces de bois d'œuvre dans l'arboretum du national de floristique de l'Université Félix Houphouët-Boigny Côte d'Ivoire. Revue de l'environnement et de la biodiversité-Pasres 3: 14-26.

Kouassi KC, 2012. Taxinomie, Ecologie et Ethnomycologie des champignons de Côte d'Ivoire: cas des macromycètes des forêts classées de Bouaflé, Bayota et Niégré. Thèse de Doctorat unique, Université Félix Houphouët-Boigny, Abidjan, Côte d'Ivoire. 172 p.

Monssou EO, Vroh Bi TA, Goné Bi ZB, Adou YCY, N'Guesssan KE, 2016. Evaluation de la diversité et estimation de la biomasse aérienne des arbres du jardin Botanique de Bingerville (District d'Abidjan, Côte d'lvoire). European Scientific Journal 12: 1857-7881.

Ouattara SFP, 2016. Diversité et densité des espèces de bois d'œuvre inscrites sur la liste rouge de I'UICN, dans l'arboretum du Centre National de Floristique de l'Université Félix Houphouët Boigny. CNF, UFR Biosciences, Université Félix Houphouët Boigny, Abidjan, Côte d'Ivoire. $60 p$

Pagny FPJ, Gouli Gnanazan ZR, Nanan KKN, Ohouko AFJ, Tiébré MS, Ouattara D, 2019. Synthèse bibliographique de quelques services écosystémiques rendus par le Centre National de Floristique. http://ci.chm-cbd.n species et/links/liens/mobilisation-de-la-communautescolaire-d-abidjan-dans-la-prise-deconscience-de/services-ecosystemiquesrendus-par-le-cnf.

Piélou EC, 1966. Species diversity and pattern diversity in the study of ecological succession. Journal of theoretical biology 10: 370-383.

Piepenbring M, 2015. Introduction to mycology in the tropics. United States of America: APS PRESS, $366 \mathrm{p}$.

Shannon CE, 1948. A mathematical theory of communications. Bell System Technical Journal 27: 379-423.

Sørensen TA, 1948. Method of establishing groups of amplitude in sociology based on similarity of content, and its application to analysis of vegetation on Danish commons. Biologisfter 5 : 1-34.

Soro B, 2020. Champignons supérieurs de Côte d'Ivoire: diversité, distribution et connaissances ethnomycologiques selon un gradient phytogéographique. Thèse de Doctorat Unique, Université Nangui Abrogoua, Abibjan, Côte d'Ivoire $252 p$.

Soro $B$, Koné NA, Vanié-Léabo LPL, Konaté S, Bakayoko A, Koné D, 2019. Phytogeographical and sociolinguistical patterns of the diversity, distribution, and uses of wild mushrooms in Côte d'Ivoire, West Africa. Journal of Ethnobiology and Ethnomedicine 15: 5.

Vanié-Léabo LPL, Yorou NS, Koné NA, Kouamé FNG, De Kesel A, Koné D, 2017. Diversity of ectomycorrhizal fungal fruit bodies in Comoé National Park, a Biosphere Reserve and World Heritage in Côte d'Ivoire (West Africa). International Journal of Biodiversity and Conservation 9: 27-44.

Yian GC et Tiébré MS, 2018. Leucoagaricus cf. americanus, an edible mushroom species poorly known of forest area of Côte d'Ivoire. International Journal of Biological and Chemical. Sciences 12: 501-507.

Yombiyeni $P, 2014$. Contribution à l'étude de la diversité taxonomique et approche écologique des polypores en forêt guinéo-congolaise au Gabon. Thèse de Doctorat Unique, Université de Louvaine. 359 p.

Yorou SN, 2000. Biodiversité, écologie et productivité des champignons supérieurs dans diverses phytocénoses de la forêt classée de WariMaro au Bénin. Thèse Ingénieur Agronome, FSA/Université Nationale du Bénin, AbomeyCalavi, $122 p$.

Yorou, NS, 2010. Higher mushrooms of Benin. Biodiversity Atlas of West Africa. Volume II Cotonou and Frankfurt/Main.

Yorou NS, Codjia JEI, Sanon E, Tchan KI, 2017. Les champignons sauvages utiles: une mine d'or au sein des forêts béninoises. Bulletin de la Recherche Agronomique du Bénin (BRAB) 16 p.

Yorou, NS et De Kesel A, 2011. Champignons supérieurs. In: Protection de la nature en Afrique de l'Ouest: une liste rouge pour le Bénin. Ibadan, Nigeria: IITA; p. 47-60. 